\title{
PSIGOLOGIESE BENADERING VAN PASTORALE
}

\begin{abstract}
ARBEID
\section{Die pastoraat}

In die spreektaal van ons Afrikaanse kerke is ons lief om die bedienaar van die Woord aan te dui as "die predikant", „die leraar" of „die dominee". Miskien plaas ons met hierdie semantiese gebruik van terme wat lering en proklamering impliseer, 'n ongelukkige klem op die preekamp. Daarteenoor, het ons semanties miskien iets te leer van die Pinkstersektes wat die benaming "pastoor" verkies, of die Amerikaanse gebruik van die term "the pastor". Ons is wel lief om te praat van „ons herder en leraar". Veelal word die herderlike, of pastorale, deel van die taak van die bedienaar van die Woord egter in sy eie gedagtes, asook in die gedagtes van sy gemeentelede, deur die leraarskap op die agtergrond gedwing. Al te dikwels word hy deur gemeentelede beskou as iemand wat op Sondag op die kansel gesien moet word en wat niks met die res van hul lewens te doen het nie. Herstel van die pastoraat sal deel moet wees van die proses om die ontkerstening van die hedendaagse lewe teen te gaan.
\end{abstract}

Die pastoraat kan, in navolging van Du Boeuff en Kuiper (1950) en andere, gesien word as 'n bepaalde vorm van verkondiging van die Woord van God. Meesal is dit Woordverkondiging wat - in al sy trefwydte - op die individuele mens gerig is, waarby rekening gehou word met die totale persoon. likheid en toestand van die mens met wie gesprek gevoer word. Soms is dit ook op mense in groepsverband gerig, bv. 'n egpaar; daar moet ook nie vergeet word dat die individu altyd verbintenisse met andere het nie.

Voordat ek verder gaan, wil ek daarop wys dat pastorale arbeid nie beperk is tot die taak van die predikant nie. Die twee ander besondere ampte in die kerk deel in hierdie taak, of behoort daarin te deel. Van die taak van die diakens sê die betrokke deel van die bevestigingsformulier dat hulle "met 'n bewoë hart en toegeneë gemoed" die armes moet help en dat dit goed is dat hulle „ook met trooswoorde uit die Heilige Skrif aan die armes en ellendiges hulp bewys". Weliswaar het ons hier te doen met 'n opdrag t.o.v. die bediening van die 
armes, maar die diakonale amp word ongetwyfeld verskraal deur verwaarlosing van die herderlike aspekte daarvan, ten gunste van materiële aspekte. Eweneens is dit 'n verarming van die ouderlingsamp dat slegs die regerende en toesighoudende take so dikwels na vore kom en dat hulle so min ,met raad en troos al die Christene dien". Dit is nie bevorderlik vir die welsyn van die kerk dat pastorale arbeid as die uitsluitlike taak van die predikant gereserveer word nie. Hierteenoor is dit egter ook so dat die praktyk meebring dat die predikant geskool is vir die diepgaande pastorale gesprek, terwyl die ouderling en die diaken in die meeste gevalle dergelike skoling mis. Gevolglik moet gewoonlik alleen die minder ingewikkelde pastorale werk aan die twee ander ampte oorgelaat word (vgl. De Klerk, 1963, p. 31).

\section{Terreinonderskeiding: Predikant en Psigoloog}

Een gevolg van die verwaarlosing van die pastoraat is dat die predikant hedendaags dikwels deur die psigoloog, die psigiater of die maatskaplike werker(-ster) vervang word. Vanselfsprekend word die mens maklik hierdeur van die godsdiens weg gelei, want dit is nie die taak van ,geestesgesondheidspersoneel" om die Woord te verkondig nie. Hierbenewens word die werklike behoefte aan hulpverlening met psigiese probleme ook dikwels van kerklike kant ontken of onderbeklemtoon a.g.v. ' $n$ te enge siening van die mens. Dit is dus nodig om die terreine van die pastor en die psigoloog hier te probeer aandui.

Voorop moet gestel word dat die pastorale gesprek die verhouding tussen die persoon en God, bygevolg die ewige sieleheil van die mens, tot besondere roepingsterrein het. Hierteenoor kry die psigoloog (en bepaald die psigoterapeut) te make met die persoon se houding tot homself en sy verhouding tot sy medemens, bygevolg die psigiese gesondheid. As gepoog word om hierdie terreine, na die een of ander kant, tot één te reduseer, getuig dit van 'n mensbeskouing wat nie werklikheidsgetrou is nie.

By onderskeiding moet egter gewaak word teen kunsmatige skeiding, want die mens is 'n eenheid waarby die onderskeie terreine mekaar wedersyds dra en lei. So bepaal die religieuse 
verhouding tot God die mens se houding teenoor homself en sy medemens as skepsels van God. Vandaar ook dat die psigoterapie nooit neutraal kan wees nie (sien bv. Lowe, 1959; Walters, 1958; Wijngaarden, 1951 en 1959).

Net so kan die pastor nie te werk gaan sonder inagneming van psigiese probleme wat die Woordverkondiging belemmer nie. Popma (1960) het in hierdie verband geskryf dat die moontlikheid om deur die losmak van emosionele knope ruimte te maak vir die verkondiging van die Woord, nie oor die hoof gesien moet word nie. „De Heilige Geest werkt immers in mensen van vlees en bloed. Ze hebben een eigen historie, een eigen karakter. Ze komen met hun eigen weerstanden, die bij historie en aard passen. Zo is het mogelijk, dat weerstanden opgeruimd moeten worden voordat psychologisch de mogelijkheid van luisteren naar het Evangelie bestaat" (p. 281).

De Klerk (1963) het die mening uitgespreek dat die pastor, vir sover hy daartoe bekwaam is, ook met psigiese middels op die terrein van die problematiek van die konflik werk. Die doel is dan om die psigiese struikelblokke vir die Woord van God uit die weg te ruim. In dié proses is die pastor dan, volgens De Klerk, ook terapeut in die ruimere sin. Let egter wel dat psigiese terapeutisering nie die uiteindelike oogmerk is nie. Wat meer is, tal van hierdie struikelblokke setel so diep in die persoonlikheidstruktuur dat die behandeling daarvan onder geen omstandighede gehanteer kan of behoort te word deur iemand wat hoogstens bykomstige kennis van psigologie en psigoterapeutiese metodes het nie.

Wanneer psigopatologie aanwesig is, d.w.s. werklike psigiese afwykings hul voordoen, is dit die terrein van die psigoloog of die psigiater. (Op gevaar van oorvereenvoudiging af, kan gesê word dat dit prakties in Suid-Afrika so is dat die psigoloog hoofsaaklik werk met minder ernstige, verbygaande afwykings a.g.v. noodspanning, en met neurotiese toestande waarby angs in verskillende manifestasies die hoofkenmerk is. Die psigiater, daarteenoor, werk hoofsaaklik met die meer ernstige psigotiese toestande wat gekenmerk word deur growwe verwringing of vervalsing van die eksterne werklikheid en waarby die behandeling dikwels grotendeels of ten volle via die liggaamlike geskied.)

Dit behoort egter duidelik te wees dat die oorgang tussen 
normaal en patologies gradueel is en dat die terreine van die pastor en psigoterapeut op hierdie grondslag nie skerp onderskei kan word nie. Dikwels sal die pastor geringer patologiese reaksies (ook vanweë praktiese omstandighede, soos die onverkrygbaarheid van ander professionele dienste) moet hanteer. Van die ander kant af betrag, sal die psigoterapeut hom nie neutraal kan terugtrek van lewensbeskoulike problematiek nie, al is dit nie sy taak om van sonde bewus te maak nie.

Daarom moet daar gepleit word vir samewerking tussen predikante met toereikende skoling in die Psigologie, enersyds, en psigoloë met 'n Christelike mensbeskouing wat hulle bewus sal maak van die vertikale dimensie van menswees, eerder as slegs die horisontale. In so 'n situasie sal die pastor weet om die hulp van die psigoloog of psigiater te verkry vir sy gemeentelid met ernstiger steurnisse, sodat dié vakmanne hulle deel sal bydra daartoe om struikelblokke tot Woordverkondiging, tesame met die ander ingrypende gevolge van die psigopatologie, uit die weg te probeer ruim. Die ander kant van die samewerking kan met 'n aanhaling uit Wijngaarden gestel word: „Is iemand in zijn geweten overtuigd van zonde en weet hij daar geen raad mee, dan zal de conflictoloog hem verwijzen naar den zielzorger, wanneer hij althans niet zelf krachtens zijn ambt als gelovige hier nog iets te zeggen heeft. In het laatste geval dient hij er zich echter van bewust te zijn, dat hij zijn vakgebied overschrijdt en niet meer spreekt als psycholoog" (1951, p. 19).

\section{,}

\section{Afwysende houdinge teen psigologie}

By baie teoloë bestaan daar ' $n$ mindere of meerdere mate van antipatie t.o.v. die Psigologie, en bepaald t.o.v. 'n psigologiese benadering van pastorale arbeid. In die algemeen vloei dit voort uit ernstige bedenkinge teen die mensbeskouinge wat deur baie psigoloë gehandhaaf word.

Die eerste steen des aanstoots is die vry algemeen waarneembare omgewingistiese determinisme wat onder die invloed van die Psigo-analise, enersyds, en van die Gedragspsigologie, andersyds, heelwat psigologiese denke kenmerk. Dergelike oorbeklemtoning van die invloed van ervaring en verlede in die veroorsaking van psigiese probleme, impliseer 'n opheffing 
van menslike verantwoordelikheid. Daarteenoor kan egter gestel word dat baie psigoloë, aan weerskante van die Atlantiese Oseaan, 'n ander mensbeskouing huldig, waarby konkrete ervaring met mense as beginpunt of as korrektief ' $n$ belangrike rol gespeel het. So het Anne Roe, bv., na intensiewe kliniese bestudering van groepe kunstenaars en bioloë gekonkludeer dat: „... maladjustment is never inevitable and that it is not unrealistic to think that a man is capable of being responsible for himself"' $(1950$, p. 341).

Hierdie determinisme mag gepaard gaan met 'n humanistiese siening van die mens as essensieel goed (bv. by Carl Rogers) of met 'n biologistiese oorbeklemtoning van die rol van die driflewe en 'n gevolglike siening van die mens as essensieel sleg (soos by Freud). Hoe dit ook al sy, bly die mens aangewese op „verlossing" deur sy medemens en deur homself. Psigoterapie is dan eintlik ' $n$ proses in die plek van bekering en die psigoterapeut is die priester van hierdie ateistiese religie. Met 'n mensbeskouing wat net op die immanente berus, kan dit ook nie anders nie. Die antwoord kan hier nie deur die psigoloog as psigoloog gegee word nie, want dit gaan om filosofiese problematiek. Wie die kennis van die Psigologie wil benut, moet hom verantwoord oor die mensbeskouing van die outeur. Hierbenewens is dit ook waar dat 'n Psigologie met 'n Christelike mensbeskouing ewe moontlik is en dat die Skrifgelowige teoloog daarby aansluiting kan vind.

Behoudende teoloëë bied soms om 'n ander rede weerstand teen 'n psigologiese benadering. Hulle het dit $\mathrm{nl}$. teen verpsigologisering van die Teologie, en veral van die Pastorale Vakke. Soms is hulle eie vakgenote die skuldiges, maar soms is dit psigoloë met heerssugtige pretensies wat te blameer is. In hulle weerstand gooi hulle egter maklik die baba saam met die badwater by die venster uit. Wurth (1953) het hieroor 'n gebalanseerde standpunt ingeneem. Hy het daarop gewys dat die Psigologie as sodanig verklaring en begrype tot doel nastreef. As gevolg hiervan dreig daar, in die algemeen genome, by elke psigologiese benadering van die menslike werklikheid die gevaar dat die normatiewe, en veral die sedelike oordeel daarby in die gedrang kom. Hy vervolg dan: „Maar dat mag voor ons geen reden zijn om tegenover die psychologie afzijdig te staan, maar alleen om haar binnen haar juiste grenzen terug te wijsen. 
Waarbij wij verder niet uit het oog moeten verliezen, dat begrijpen zowel als beoordelen elk hun eigen functie in de benadering van de medemens bezitten" (pp. 7-8).

'n Nog meer ekstreme houding vloei uit die piëtistiese of perfeksionistiese opvatting voort dat waarlike Christen-wees psigiese probleme uitskakel. Al wat dan nodig sou wees, is bekering. Kennis van die Psigologie en sy benaderingswyses word dan, vanselfsprekend, oorbodig en 'n behoefte daaraan by die pastor word bewys van nie-regverdigheid. In 'n ander verband kom ek later op hierdie vraagstuk terug. Voorlopig wil ek egter daarop wys dat gelowigheid en psigiese gesondheid begrippe is wat te doen het met menslike funksies en toestande van menswees wat nie tot mekaar herleibaar is nie.

\section{Behoefte aan psigologiese mensekennis}

\section{Normale mens in sy totaliteit}

'n Predikant is ook 'n onvolkome mens. Daarom bestaan daar vir hom die wesenlike gevaar dat hy sy medemense, vanweë sy wetenskaplike spesialisasie, sowel as vanweë sy sosiale rol, effens verwronge mag waarneem. Enersyds bestaan daar die gevaar van oorbeklemtoning van die geloofsfunksie, om die mens hoofsaaklik as religieuse wese te beskou. Andersyds bestaan daar gevaar van moralisme, van te opereer met abstrakte etiese skemas, sonder om aandag te bestee aan die lewende mens met al sy konkrete lewensnood en lewensmoeilikhede (vgl. Wurth, 1953). Daarby kom die gevaar dat die pastoraat onwillekeurig in 'n mate op die agtergrond gedring mag word deur teologiese en kerklike kwessies (vgl. Harder, 1953).

Hierdie probleme word vererger deurdat gemeentelede nie slegs verwag dat hulle predikant ' $n$ bepaalde sosiale rol moet vertolk nie, maar self ook 'n heel besondere rol teenoor hom en in sy teenwoordigheid probeer speel. Die meeste ervare predikante is hiervan bewus, maar ek betwyfel of hulle, by gebrek aan 'n basis vir vergelyking, altyd die omvang van hierdie rolvertolking kan besef. So baie aspekte van die lidmate se lewens word vir die predikant verberg of verdraai.

Die enigste korrektief vir die voorgenoemde probleme in die omgang met gemeentelede is mensekennis. Christus het 
gesê dat Hy, as goeie Herder, Sy skape ken (Joh. 10 : 14). Die betekenis van hierdie woord „ken" impliseer hier dat op 'n liefdevolle wyse rekening gehou word met beide goeie en swak hoedanighede. Uit menslike oogpunt beskou, is dit ook die fondament van die pastoraat in die kerk van Christus. Die predikant moet die mens grondig ken in sy skynheiligheid, sy twyfel, sy angs, sy verveling, maar ook in sy vreugde, entoesiasme en liefde.

Ek het reeds die gedagte van Popma aangehaal dat die Heilige Gees in mense met eie karakters, weerstande en geskiedenisse werk. Daarby wil ek ook De Klerk aanhaal: „Die waarde van die psigologie vir die pastoraal is dat dit 'n breër en dieper insig in die psigologiese struktuur van die mens gee wat die substraat vorm van die Gees se genadewerk in ons" (1963, p. 9; kursivering weggelaat). Nou wil ek vir geen oomblik te kenne gee dat die predikant (of die psigoloog!) al die nodige mensekennis kan verkry deur akademiese bestudering van die Psigologie nie. Daar is geen substituut vir ervaring deur met mense saam te lewe nie. Die predikant wat as medemens kan verkeer, sal van hulle kan leer - en ook lewenslank kan aanhou. (Eintlik is dit nodig dat die propedeutiese en teologiese student alreeds voordat hy 'n afgebakende sosiale rol toegeken kry, vryelik met mense in ander hoedanighede as die akademiese te doen kry. 'n Praktiese oplossing is vakansiewerk in 'n verskeidenheid van situasies.)

Bloot praktiese mensekennis is egter ook weer nie genoeg nie. Uiters waardevol daarby is wetenskaplike bestudering van die individuele mens in sy ontwikkeling van suigelingskap af tot bejaardheid, in sy pogings tot aanvaarding van homself, van sy medemense in die algemeen en van 'n lewensmaat in die besonder, in sy soeke na $\sin$ in die lewe, in sy konflikte en psigiese afwykings - kortom, bestuderings van die Psigologie van die mens. Enersyds sal dit direk kennis bybring. Maar verder sal dit werkwyses leer om mense te observeer en te leer ken, benaderingswyses wat alledaagse geleenthede tot die opdoen van mensekennis soveel nuttiger sal maak.

Dit word almeer kenmerkend van die Psigologie dat die mens in sy totaliteit bestudeer word. Die psigiese funksionering op sigself, maar ook in verband met die biotiese, sosiale, etiese en religieuse, word ondersoek met die hoop op verklaring en 
begryping. Hierdie totaliteitsvisie kan ook op die pastoraat bevrugtend inwerk. Ek sal probeer illustreer.

'n Gevaar by die vergeesteliking van die mens is dat die liggaamlike verag kan word. Teologiese etiek word dikwels gekenmerk deur 'n soort asketisme waarin die rol van die biotiese driflewe onderbeklemtoon, of selfs verdring word. Daarteenoor eis die omstandighede van 'n gemeentelid soms dat die pastor ook op die waarde van die liggaamlike, selfs bepaald die seksuele, moet wys en daaroor voorligting moet gee.

'n Effens persoonlike voorbeeld hiervan uit die pastoraat van my vader, sal my seker vergewe word. Die ongelukkige situasie het hom voorgedoen dat 'n egpaar van oor die sestig wou skei. Die dominee en ouderling het die ou broeder en suster gaan besoek. Later het ek as kind gehoor hoe my vader die probleem met my moeder bespreek het. (Die aanhoor daarvan het waarskynlik bygedra tot my eventuele belangstelling in die Psigologie!). 'n Brokstuk wat ek goed onthou was dat hy vertel hoe hy, tot verstomming van egpaar en ouderling, gevra het of hulle nog vry en hulle daarna vermaan het oor die verwaarlosing van liggaamlike liefdesblyke soos omhelsing en soen.

Om egter ook 'n voorbeeld uit die meer psigiese sfeer te gee: As 'n mens mynwerkers bogronds (bv. as kerkmense), sowel as ondergronds leer ken het, kan jy die verskil dikwels moeilik glo. 'n Besadigde man word 'n paar duisend voet ondergronds ' $n$ luide vloeker of selfs 'n aggressiewe aanrander. As ' $n$ mens in hierdie gedrag 'n sekere element van afweer of bravado sien, van 'n mens wat hom nietig voel in 'n eintlik immer vreemde element, waarin altyd rekening gehou moet word met gevaar van plotselinge besering of dood, en waarin die onbekende altyd vae angsgevoelens wek, dan temper die blik op die psigiese jou religieus georiënteerde oordeel. Dan sien jy agter die woeste lummel die bang seuntjie wat in die donker loop en fluit en wat smag na ' $n$ hand wat sy handjie kan vashou.

Daarby wil ek De Klerk weer aanhaal: „Die poging om in die pastorale ontmoeting te begryp, mag die oordeel nie neutraal maak nie, maar ewemin mag die oordeel in die plek van die begrype kom" (1963, p. 49; kursivering weggelaat). 
Neurotiese en psigotiese verskynsels

Hierbo het ek kortliks verwys na die vraagstuk of herstel van die verhouding tot God, nie ook psigiese gesondheid impliseer nie. Die omgekeerde word selfs geinsinueer, dat psigiese afwykinge nie by ware Christene voorkom nie. In hierdie verband het Wijngaarden (1951) daarop gewys dat die geloof die sondigheid nie wegneem nie, en ewemin die psigiese en liggaamlike gevolge daarvan in siekte, dood, psigiese stoornisse, ens. Hy beklemtoon dat in die eenheid van die gehele menslike geslag elke mens deel het aan die gevolge van die kollektiewe sondigheid van Christene en nie-Christene van vandag, maar ook van vorige geslagte. Lyding en nood val allermins saam met persoonlike skuld. Ter illustrasie noem hy opvoedingsfoute in die gesin of skool, maatskaplike wantoestande (soos woningnood), misvattings wat eie is aan 'n bepaalde kultuurperiode (bv. oor die seksualiteit), elk waarvan 'n groeibodem kan vorm vir psigiese versteuringe.

Elders wys dieselfde skrywer (Wijngaarden, 1959) ook daarop dat die geloof in elke leeftydsfase deur psigiese remminge van allerlei aard in sy ontwikkeling geskend of selfs geperverteer kan word: „Juist omdat de oorsprong van deze remmingen onbewust is, maakt ook een echt geloof een analyse niet overbodig. Wanneer iemand innerlijk dreigt vast te lopen, behoeft immers de oorzaak daarvan niet te liggen in een gebrek aan geloof, maar kunnen veeleer dezelfde remmingen daaraan schuldig zijn, die ook de vrijheid van het geloofsleven beknotten" (p. 203).

Ook Wurth (1955) wys daarop dat by elke mens verdronge komplekse voorkom, met allerlei verkeerde dade, drifte, neigings, voorstellings wat in die onderbewuste teruggesink is en waarvan die persoon hom weinig of niks herinner nie; skaamte voor God en voor medemens laat ons onbewus daarteen weerstand bied om eerlik daarmee voor die dag te kom. Hierdie komplekse veroorsaak egter psigiese en psigosomatiese stoornisse. En geen mate van betreklik rasionele of intellektuele Woordverkondiging sal dié stoornisse kan opklaar nie.

Dit behoort dus duidelik te wees dat 'n sekere mate van kennis omtrent psigiese afwykingstoestande 'n deel van die toerusting van die pastor moet wees. Deels is dit direk nodig vir 
sy pastoraat. Andersyds is hy dikwels die aangewese persoon om reëlings te probeer tref om 'n gemeentelid met sodanige probleme by die psigoloog of die psigiater te kry. Wanneer lg. gebeur, moet sy pastorale werk voortgaan, maar dan is kennis van die Psigologie nuttig om hom te help om intelligent met die psigoloog of psigiater saam te werk.

Graag staaf ek hierdie bewerings weer met 'n aantal voorbeelde:

Eerstens wil ek 'n voorbeeld van Wijngaarden (1951) aanhaal om te illustreer hoe die pastoraat direk geraak word. Hy toon aan hoe, by 'n persoon in wie se lewenshouding 'n negatiewe vaderbinding deurwerk, angs en wrok teen die wrekende en straffende God ten nouste kan saamhang met sy onopgeloste vaderprobleem. Dit is slegs 'n projektering van die negatiewe vaderbeeld op God. Hierdie probleem verhinder hom om die God van liefde te vind oor wie hy net hoor praat. Waterink het by geleentheid (te Potchefstroom, 1959) hierby die moontlikheid genoem dat ' $n$ negatiewe moederbeeld 'n persoon weerstand kan laat bied teen géwende figure in die algemeen, wat dan ook Christus en Sy soenoffer vir so iemand emosioneel onaanvaarbaar maak.

My tweede voorbeeld kom uit Hutter (1953) en illustreer hoe 'n ernstige neurotiese toestand by 'n gelowige mens kan voorkom. Hy verhaal kortliks die geval van 'n neurotiese toestand by ' $n$ jong meisie wat in 'n religieuse sfeer opgevoed is, wat op 25-jarige ouderdom groot angste ondervind het, bang was om haar op straat te begeef, gevrees het dat sy sou sterf, maar ook religieus pynlik pligsgetrou was tot in die kleinste sake. Dit het geblyk dat sy van geboorte- en huweliksvrae nog vrywel niks geweet het nie, dat sy seksualiteit as sonde gesien het en sterwe beter as lewe geag het. Dit was nodig om haar op te wek tot aanvaarding van natuurlike drifte as geskape en deur God gewilde groothede. Haar genesing was in seksuele ryping geleë. Hoewel dergelike gevalle die hulp van 'n psigoloog of 'n psigiater verg, moet die pastor genoeg van neuroses weet om dit te herken.

'n Derde voorbeeld is skuldgevoelens, iets waarmee die pastor dikwels by gemeentelede te doen kry. In sy geheel is die kwessie van skuldgevoelens ' $n$ omvangryke probleem. Wurth (1955) waarsku daarteen dat van psigoanalitiese kant dikwels al 
te maklik aan neurotiese skuldgevoelens gedink word, maar voeg ook by dat daar heelwat is wat vir ware skuldgevoel uitgegee word, wat in werklikheid slegs op sieklike, infantiele selfbeklag neerkom. Aan die hand van Rümke onderskei hy as volg: infantiele skuldgevoel ontstaan daaruit dat die persoon gebrek gely het t.o.v. die ontvang van liefde (tydens ontwikkeling), terwyl rype skuldgevoel sig openbaar as 'n mens tot die insig kom van 'n tekort in die gee van liefde.

Nog 'n vorm van skuldgevoel waarby die pastor op sy hoede moet wees, is dié van die psigoties-depressiewe persoon. Die ou mense het gesê so iemand is ,in 'n stryd". Hier het ons te doen met waandenkbeelde van sonde: die persoon is diep besorg, selfs wanhopig oor allerlei sondes wat hy werklik of denkbeeldig begaan het. Die gevaar is dat die oningeligte dit kan sien as die geloofstryd van 'n diep gelowige, met hom daaroor herderlik gesprek voer, ens. Twee dinge behoort gevaartekens te wees: (i) dikwels voel die persoon so geweldig skuldig oor oortredinge wat in werklikheid byna onbenullig is en wat haas by alle mense byna alledaags is, terwyl hy ander oortredinge van 'n werklik ernstige aard uit die oog verloor; (ii) die depressiewe persoon reageer dikwels op enige gerusstelling met uitermatige wanhoop, bv. deur te beweer dat sy skuld so groot is dat selfs Christus hom nie kan help nie. So 'n persoon moet so gou as moontlik onder psigiatriese sorg geplaas word, o.a. omdat die risiko van selfmoord groot is. Tot tyd en wyl psigiatriese behandeling die akute depressie laat opklaar het, kan die pastor eintlik slegs belangstel. Gewoonlik kan hy die huisgenote van dié persoon onder sulke omstandighede meer help.

\section{Psigologiese benadering in praktyk}

Psigiese funksionering van pastor

I.v.m. die praktiese implimentering van 'n psigologiese benadering is daar, in die oog lopend, die kant van die psigiese funksionering van die gemeentelid. Ten minste van ewe groot belang is egter om nie uit die oog te verloor dat die pastor self ook ' $n$ mens met psigiese hoedanighede en behoeftes is nie. Ook in sy geval verseker diepe gelowigheid nie vrywaring van psigiese probleme nie. En teologiese opleiding bly hoofsaaklik 
op die intellektuele vlak, wat geen versekering inhou dat dit met die em^sionele reg is nie.

Die pastor moet van dag tot dag help dra aan die persoonlike probleme van ander mense. Hy het heel dikwels met traumatiese situasies te doen - hoe skokkender die mens se ervaring is, hoe groter die waarskynlikheid dat hy dit van sy predikant sal onthou. Die aanhoudende, chroniese probleem waarvoor daar geen uitkoms skyn te wees nie, stel egter waarskynlik nog hoër eise. Verder is daar die byna reëlmatige ervaring van persoonlike frustrasie: die gevoel van teleurstelling en dwarsboming wat die pastor oorweldig wanneer sy beste pogings vergeefs blyk te wees. Al hierdie dinge verg dat die predikant self psigies gesond moet wees. Uit die aard van die saak, kan 'n mens hier nie 'n streep trek tussen psigiese gesondheid en gelowigheid nie, en laasgenoemde is 'n sterk steun tot eersgenoemde. Dat die omgekeerde ook waar is, moet ons egter nie uit die oog verloor nie.

Die aspek van psigiese welsyn wat ek hier die meeste wil beklemtoon, is dié van selfaanvaarding. Met ,aanvaarding" bedoel ek nie 'n houding van ,jou maar daarby neer te lê" nie. Inteendeel is dit 'n aktiewe, vrywillige, verantwoordelike proses van innerlik ,ja" te sê op die opdrag wat in bepaalde lewensituasies geleë is. T.o.v. aanvaarding van jouself beteken dit 'n instemming met die kombinasie van hoedanighede en lewensomstandighede wat jouself kenmerk - 'n ingestemdheid soos wat snare ingestem is om in harmonie met mekaar te vibreer. (Dit is 'n omvangryke aangeleentheid hierdie en dit sou enigeen die tyd loon om te lees wat Wijngaarden (1959) daaroor geskryf het.)

Die selfaanvaardende persoon word gekenmerk deur uiterlike en innerlike selfstandigheid. Dit veronderstel 'n aflegging van die kinderlike afhanklikheid van ouers en ander volwassenes, en 'n wil om volgens eie insigte en beslissinge op jou eie bene te staan.

Verder word hy gekenmerk deur 'n bereidheid tot kennis van homself, of negatief gestel, die afwesigheid van ontkenninge omtrent homself. Dit raak 'n mens se swakhede en tekortkominge, wat dikwels swaar erken word deur die persoon wat deur andere in hoë aansien gehou word. Dit is bv. so swaar vir die pastor om teenoor homself en andere te erken dat 
hy nie is wat Harder noem ,de gestroomlijnde pastor, die voor alles een oplossing en met alles raad weet" (1953, p. 31). Dit raak egter ook sy gawes en bekwaamhede, wat hy ewewigtiglik moet herken vir wat hulle is, d.w.s. sonder opgeblase selfverheffing op verkleinerende ontkenning. By elke mens is daar 'n sterk behoefte om hom te laat geld, om vernaam te wees. Die hoë posisie van die predikant onder ons Afrikaners bevorder maklik so ' $n$ oorwaardering van eie talente. Aan die ander kant meen sommige mense dat Christelike nederigheid oorbeskeidenheid en selfminagting vereis. ' $n$ Werklike openheid tot selfkennis sal verhoed dat die pastor hom in hierdie uiterstes vasloop. Eintlik kom dit neer op 'n nederige dankbaarheid vir wat 'n mens sonder jou eie toedoen ontvang het, maar ook op eerbied vir die self wat so begenadig is.

Die laaste aspek van selfaanvaarding wat ek wil noem, is die oorgegewenheid aan die taak wat aan hom in die besonder gestel is. Dit is 'n saak van meningsgevoel, van ' $n$ mens se taak in 'n ewigheidsperspektief te sien. So gesien, verdwyn die sleur, die eentonigheid, die beuselagtigheid, die frustrerendheid wat dikwels ook deel is van 'n predikant se werk. Uit die aard van hulle lewenstaak is dit 'n aspek wat teenoor predikante seker nie veel beklemtoning benodig nie. Die vraag is net of ons elkeen dit werklik in besonderhede psigies verwerk. Dikwels vorm ons net die woorde met ons mond, sonder om met ons hele lewe daarvan te spreek.

Selfaanvaarding is van die allergrootste belang, aangesien die afwesigheid daarvan aanvaarding van andere verhoed. Die persoon wat, bv., onseker voel oor sy eie waarde en dit probeer bewys, het ' $n$ behoefte aan mag en wil andere beheer. Te dikwels voel ook predikante dat hulle iets aan hulle gemeentelede moet doen. Hulle voel dat hulle nie behoorlik funksioneer tensy hulle kan beveel, rig, voorskryf of adviseer nie. Daarteenoor staan die persoon wat homself aanvaar, oop en ontvanklik vir sy medemens. 'n Optimale hulpgewende verhouding stel beslis hierdie eis aan die helpende persoon. Ook t.o.v. Woordverkondiging is dit 'n voorvereiste, want die persoon van die pastor kan die weg na Christus vertroebel of vergemaklik (vgl. De Klerk, 1963, p. 55).

Om psigiese ewewig te kan bly bewaar, is dit ook vir die pastor nodig om gereelde geleenthede te hê om met iemand 
anders vertroulik te kan praat oor sy moeilikhede, frustrasies en vertwyfelinge. Om alles vir ' $n$ mens self te probeer hou is gevaarlik. Daarteenoor bring uitpraat verligting en insig, ook vir die pastor wat in dié geval eintlik self 'n pastor nodig het. Hier kom die eggenote van die predikant as hulpe aan sy sy in; maar soms is sy te naby en self te veel betrokke. Soms vind 'n predikant in 'n vertroude lewenswyse ouderling die hulp wat hy nodig het. $D$ it is baie goed om 'n vertroude broeder in die bediening te hê met wie gereeld openhartig gesels kan word. As die predikant self (of met die hulp van andere) van psigologiese probleme by homself bewus word, moet hy daarvoor professionele hulp soek; andere kan bekostig om maar te laat loop en te hoop dat tydsverloop sal help, maar die stremming van die pastoraat maak dit 'n waagstuk. Al dié dinge lyk vanselfsprekend, maar die aktiewe pastor kan dit nooit te goed in gedagte hou nie. Die pastor is dienaar en die dienaar mag onder geen omstandighede toelaat dat sy diensbaarheid verminder word deur voorkombare kwellinge en konflikte nie.

\section{Houdingsagtergrond}

Waarskynlik is een van die belangrikste bydraes wat die Psigologie tot die benadering van medemense lewer, die beklemtoning van die rol wat houdinge speel. Daar gaan 'n uiters bepalende invloed uit van die houdinge wat die agtergrond vorm van wisselwerking tussen mense.

Die eienaardige daarvan is dat, nieteenstaande hierdie houdinge dikwels volkome onbewus is, hulle tog meegedeel en waargeneem word. As 'n persoon ' $n$ vyandige houding teenoor 'n gespreksgenoot het, hoef hy dit nie bewustelik met die mond aan hom te sê nie. Die gespreksgenoot „voel dit aan" en reageer dikwels toepaslik daarop - sonder dat een van die twee dié houdingsagtergrond onder woorde sou kon bring: „Intuïtiewe waarneming" is 'n benaming daarvoor, maar nie 'n verklarende beskrywing van die gebeure nie. Kommunikasie vind in 'n groot mate nie-verbaal plaas, deur stembuiginge, tempo van spraak, stilswye op bepaalde momente, maar ook deur gesigsuitdrukkings, liggaamshouding en gebare. Aangesien dit egter die geval is, is dit duidelik dat bv. die pastor nie moet probeer huigel in sy verhoudinge met andere nie. 
Wanneer iemand, bewustelik of onbewustelik, 'n bepaalde houding teenoor hom by 'n ander waarneem, reageer hy dienooreenkomstig daarop. As die houding gunstig is, reageer hy met toegeneentheid. As die houding ongunstig is, reageer hy met afweer of aanval. Wil die pastor dus 'n goeie gesindheid teenoor die saak waarvoor hy staan verwek, moet hy in gedagte hou dat die goeie gesindheid by hom moet begin.

Wat nodig is t.o.v. houdingsagtergrond is ' $n$ positiewe ingesteldheid van belangstelling, agting en aanvaarding van die medemens, sonder om voorwaardes te stel. Die betekenis wat ek tevore aan die begrip „aanvaarding” geheg het, moet ook i.v.m. aanvaarding van andere in gedagte gehou word. Carl Rogers het hierdie aspek baie sterk en duidelik gestel, o.a. as volg: „It involves as much feeling of acceptance for the client's expression of negative, 'bad', painful, fearful, defensive, abnormal feelings as for his expression of 'good', positive, mature, confident, social feelings, as much acceptance of ways in which he is inconsistent as of ways in which he is consistent" (1957, p. 98$)$.

Ook kom dit daarop neer dat 'n verhouding geskep word waarin die persoon bevry word van eksterne evaluasie. Dwarsdeur ons lewens, in alle situasies word ons onderwerp aan positiewe en negatiewe evaluasies. Ons word daardeur so gekondisioneer dat ons dikwels nie self wil besluit of iets reg of verkeerd is nie, maar ons slegs afvra wat ander mense daarvan sal dink. In 'n ander artikel wys Rogers (1961) daarop dat, eienaardig genoeg, 'n positiewe evaluasie op die lang duur net so bedreigend is as ' $n$ negatiewe. Om aan 'n persoon te kenne te gee dat hy goed is, impliseer ook dat jy die reg het om hom te kenne te gee dat hy sleg is. „So I have come to feel that the more I keep a relationship free of judgment and evaluation, the more this will permit the other person to reach the point where he recognizes that the locus of evaluation, the center of responsibility, lies within himself" (p. 109).

Wurth (1955) het soortgelyke gedagtes met die optrede van Christus toegelig. „Waarom zijn tal van zondaars tegenover Christus zo eerlijk geworden en hebben zij zo al hun schuld voor Hem beleden? Omdat zij gevoelden, dat, al doorzag Hij hen volkomen, Hij toch er niet over dacht de eerste steen op hen te werpen" (p. 229). Wijngaarden (1951) het ook verwys 
na die geskiedenis van die vrou wat in egbreuk betrap is (Joh. $8: 3-11$ ) en die aandag daarop gevestig dat Jesus nie gemoraliseer, nie straf of boete opgelê of veroordeel het nie. Inteendeel, Hy het die sondige mens herken met wie Hy desondanks ến gebly het. Hy het Hom nie bo haar verhef nie, maar eerder naas haar gaan staan.

Wannecr iemand beleef dat hy sonder voorwaarde of kritiek, tewens onbevange en welwillend ontvang word, net soos hy is, skep dit by hom 'n gevoel van veiligheid en geborgenheid. Dit skep vrymoedigheid om eerlik na homself te kyk en vryuit oor homself te praat. As hy verseker voel dat hy nie geminag of verag sal word nie, hoef hy nie meer weg te steek en te verswyg nie. Daarmee begin openhartige selfontdekking. Dit voer tot ware kennis van sonde en ellende, maar ook tot ontvanklikheid vir die verkondiging van die Boodskap van Verlossing.

'n Gedagtegang soos hierdie wek maklik by die leser 'n gevoel dat dit moontlik te ver gaan, moontlik selfs humanisties kan wees. Die belangrikste onderskeid waarop die aandag egter gevestig moet word, is dat daar slegs sprake is van aanvaarding van die mens, van die sondaar, maar geensins by implikasie ook van die sonde nie. Die beskrewe houding voer nie tot normlose toegeeflikheid en gevolglike aanmoediging tot verdere oortreding nie. Die voorbeeld van Christus spreek, weer eens, boekdele wanneer $\mathrm{Hy}$ aan: „Ek veroordeel jou ook nie”, toevoeg: "Gaan heen en sondig nie meer nie". Die hele voorafgaande situasie en die direkte aanvaarding van die sondares het ontsaglike krag verleen aan die opdrag tot opstanding as nuwe mens.

Terloops, wil ek ook daarop wys dat hierdie houding van positiewe agting die enigste uitgangspunt kan wees vir gesprekke met buitekerklike en sektemense. Die houding van vyandigheid en afkeer waarmee sulke mense dikwels benader word, doem alle pogings om hulle oor te win. Met waardigheid kan hulle waardigheid erken word. Om voorbeelde van Hutten (1957, p. 141) aan te haal: Wie met sektariërs in gesprek wil tree, moet nie die erns van hul oortuigings in twyfel trek nie, moet hulle nie as kwaadwillige of minderwaardige mense behandel nie, moet nie oor hulle leer of lewe valse getuienis gee nie, moet hulle nie persoonlik in diskrediet bring, laster 
of krenk nie. Inteendeel, hy moet opkom teen onware vooroordele wat oor hulle in omloop is, en selfs die baie goeie dinge wat hulle kenmerk en wat dikwels die kerke tot beskaming is, erken en waardeer. Andersyds sal hy beterwetery, aanmatiging en fanatisme wat hy by hulle teëkom, met geduld tegemoet tree.

\section{Empaties luister}

Vir die predikant wat opgelei en geoefend is in die kuns om te preek, en van wie lidmate dit ook verwag, is die gevaar baie groot dat hy 'n alleenspraak mag aansien vir 'n gesprek. „Het is ... wel een trieste zaak, dat zoveel mensen van dominees beweren, dat ze zo slecht kunnen luisteren. Er moet bepaald daartoe wel aanleiding gegeven zijn, gelet op de frequentie van deze klacht" (Van der Schoot, 1960, p. 264). As 'n aanvaardende houding egter by die pastor aanwesig is, sal ' $n$ bereidheid om ook te luister byna as vanself daaruit voortvloei. Ook vir die pastor geld dat die getalsverhouding tussen ore en mond: twee tot een, die verhouding moet aandui waarin 'n mens hulle moet gebruik. Daarby kom dat 'n mens ook kan leer om bewustelik aandag te gee aan die bogenoemde nieverbale mededelinge.

By 'n hulpgewende gesprek word egter veel meer as net passiewe aanhoring geverg. 'n Aktiewe instelling van empatie of „Einfühlung” is nodig. Dit beteken dat die luisteraar hom as 't ware binne-in die spreker in moet projekteer, ten einde sodoende te kom tot volle begrip van wat gesê word. Dit is nie slegs 'n intellektuele instelling nie, maar 'n emosionele meelewing. In die woorde van Rogers beteken dit: „To sense the client's private world as if it were your own, but without ever losing the 'as if' quality... To sense the client's anger, fear, or confusion as if it were your own, yet without your own anger, fear or confusion getting bound up in it" (1957, p. 99). Elders definieer hy empatie as: „... the ability to accompany a person wherever his feelings lead him - no matter how strong, deep destructive, or abnormal they seem" (Rogers, 1961, p. 108).

Om te vind dat iemand anders nie bevrees is om saam met hom die donker dieptes van sy verwarde gevoelens en gedagtes te betree nie, laat hom voel dat hy nie verlate, afgesonderd, totaal anders, totaal sonder hoop is nie. Dit help hom om te 
praat oor diep verborge dinge. Dit laat diep verdronge gevoelens opwel en tot dié normale afloop kom wat nog nooit aan hulle toegelaat was nie. Sodoende kom daar emosionele ontlading en verligting. Dit berei weer die weg voor vir beter selfinsig. Saam daarmee kom ook 'n ordening van gedagtes: deur dit aan die luisteraar te probeer verduidelik, kry die spreker self ook insig daarin. So voer ook die invoelende aanluister die spreker tot selfontdekking.

\section{Begrypende benadering}

'n Laaste belangrike aspek van die psigologiese benadering is om nie die uiterlike optrede en intellektuele gedagte-inhoude van mense sonder meer op die gesigswaarde daarvan te aanvaar nie. Ons moet trag om die werklike gevoelsagtergrond en die emosionele doelmatigheid daarvan te verstaan en in te sien. Ons moet agterkom wat met en in die persoon omgaan. Ons moet die verborge dryfvere en oogmerke probeer peil. Weliswaar moet ons daarby versigtig wees vir die Freudiaanse uiterste van niks anders te sien nie as maskers, waaragter ook niks anders as perverse, neurotiese dryfvere skuil nie. Maar die ander uiterste, van hoofsaaklik bewuste inhoude in ag te neem en vir die volledige werklikheid te hou, openbaar miskien selfs meer onkunde.

'n Mens moet versigtig wees om 'n verskynsel nie in sy afgesonderdheid te probeer verstaan nie. Dit kan slegs in die onderlinge verband, in die innerlike samehang werklik begryp word. Die rede is dat geen psigiese verskynsel of proses toevallig of doelloos is nie. Ons kan 'n verskynsel verstaan alleen as ons weet wat die doel daarvan is en watter plek dit inneem ter verwesenliking van dié doel. Elke psigiese verskynsel moet in sy teleologiese verband gesien word.

De Klerk (1963) spreek die mening uit dat as die gesprek alleen op die denkwlak beweeg, dit die werklike mens, wat hom graag agter die maskers van sy gedagtesisteem wil verberg, mis tas. Die gevoelsagtergrond is feitlik deurgaans belangriker as die objektiewe feite wat in die gesprek meegedeel word. Die hele bestaan van die mens is betrokke in elkeen van sy probleme. Ook die wat in godsdienstige terme gekleed 
is, het ' $n$ emosionele draagwydte en kan nie van die res van die mens losgemaak word nie.

Miskien sal enkele voorbeelde weer die saak kan toelig.

By adolessente is weerspannige verset teen eise van onderwerping aan gesag en teen opvattings wat deur gesag gedra word, betreklik tipies. Die pastor moet hier baie stadig wees met beklemtoning van gehoorsaamheid en met oppervlakkige interpretasies dat betwyfeling van algemeen aanvaarde geloofsinhoude opstand is teen God en sy gebod. Veelal het ons hier te doen met 'n ontwakende selfgevoel, waarteen aanvaarding op grond van tradisie en ouerlike of kerklike gesag ten enemale indruis. Terselfdertyd is daar 'n gevoelsagtergrond van onsekerheid: daar is onsekerheid, selfs vertwyfeling oor eie bekwaamheid. Dit kan egter nie erken word nie, en die teendeel word met heftige verset verdedig by die geringste insinuering van onbekwaamheid. Veroordeling en betigtiging sal hier slegs tot vervreemding aanleiding gee. 'n Simpatieke blik op die totale situasie sal baie meer regkry.

Soortgelyke weerbarstigheid, met argument op argument, kenmerk soms ook ouer mense wat in hulle ontwikkeling gerem is. Die pastor moet by dergelike gevalle hom vergewis of die oorsaak daarvan nie miskien te vinde is in ontmoedigende jeugervaringe of in spanninge rondom die verhouding tot die ouers, veral tot die vader nie. (Vgl. Harder, 1953.)

Ek herinner u ook aan my vroeëre voorbeeld van die vloekende, dreigende mynwerker.

Die konkrete persoonlike lewensomstandighede van die persoon moet met opmerksaamheid en geduld betrag word, ten einde die mens werklik te begryp. Ons moet 'n geheelperspektief probeer kry op die sameloop van omstandighede van verlede en hede, tesame met die hoop en wanhoop vir die toekoms. Ons moet die eie aard van hierdie persoon en sy eenmalige konstellasie van lewensfaktore probeer sien, verstaan en aanvoel.

Dikwels is dit so dat, van menslike kant gesien, die arme mens se enigste hoop daarin geleë is dat hy deur sy pastor verstaan word. Dikwels is dit sy enigste hoop op selfbegrip en bevryding van emosionele boeie. Deur die genade van God is dit ook dikwels sy enigste hoop om tot selfkennis omtrent sy in-sonde gevallenheid te kom, maar tewens ook op ,'n hartlike vreugde deur Christus" en op "lus en liefde om na die 
wil van God in alle goeie werke te lewe" (Heidelbergse Kategismus, 90).

\section{Slotgedagtes}

Psigologiese kennis en kundigheid mag die pastor help om ernstige psigiese afwykings betyds raak te sien, om verborge motiewe te begryp en tot bewustheid te bring, en om 'n doeltreffende gespreksverhouding te bewerkstellig. As sodanig is die Psigologie 'n hoogsbelangrike hulpwetenskap van die Pastoraal. Die psigologiese benadering moet egter nooit hoofsaak word nie. Dit moet altyd in 'n instrumentele hoedanigheid gesien word. Geen hoeveelheid pastoraal-psigologiese kennis en kundigheid kan op sigself die mens tot ware sondebesef en tot aanvaarding van die Heilsboodskap bring nie. Dít vermag slegs die Heilige Gees.

Vakkomitee vir Psigologie,

D. J. W. Strümpfer. Universiteit Port Elizabeth

\section{LITERATUURVERWYSINGS}

De Klerk, W. J. (1953): Die pastorale gespreksontmoeting - 'n prinsipiële studie. Ongepubliseerde Th.M.-skripsie, P.U. vir C.H.O.

Du Boeuff, C. W. en Kuiper, P. C. (1950): Psychotherapie en zielszorg. Utrecht, Bijleveld.

Harder, R. C. (1953): De waarde van de psychologie voor het practische pastorale werk. Referaat voor Vereeniging ter Bevordering van de Geestelijke Volksgezondheid op Geref. Grondslag: Rotterdam: Donner.

Hutten, K. (1957): Geloof en sekte (vertaal deur J. J. Poort). Franeker: Wever.

Hutter, A. (1953): De psychoterapie tegen de achtergrond der christelijkreformatorische wereldbeschouwing. Referaat voor Vereniging ter Bevordering van de Geestelijke Volksgezondheid op Geref. Grondslag. Rotterdam: Donner.

Lowe, C. M. (1959): Value orientations - an ethical dilemma. Amer. Psychologist, 14, 687-693.

Popma, S. J. (1960): Zielszorg en pastorale counseling. Bezinning, 15, $272-282$.

Roe, Anne (1950): The use of clinical diagnostic techniques in research with normals. In Reymert, M. L. (red.): Feelings and emotions. New York: McGraw-Hill.

Rogers, C. R. (1957): The necessary and sufficient conditions of therapeutic personality change. $J$. consult. Psychol., 21, 95-103. 
Rogers, C. R. (1961): The characteristics of a helping relationship. In Stein, M. I. (red.): Contemporary psycho-therapies. New York: Free Press of Glencoe.

Van der Schoot, E. (1960): Gesprek en contact. Bezinning, 15, 257-269.

Walters, O. S. (1958): Metaphysics, religion, and psychotherapy. J. counsel. Psychol., 5, 243-252.

Wijngaarden, H. R. (1951): Enige beschouwingen over de conflictuologie. Groningen: Wolters.

Wijngaarden, H. R. (1959): Hoofproblemen der volwassenheid. Utrecht: Bijleveld.

Wurth, G. B. (1953): De betekenis van de psychologie voor de theologische praxis. Referaat gehou voor Vereniging ter Bevordering van de Geestelijke Volksgezondheid op Geref. Grondslag. Rotterdam: Donner.

Wurth, G. B. (1955): Christelijke zielzorg in het licht der moderne psychologie. Kampen: Kok. 